Merve CELIK

Lecturer, Bingol University

Health Science Vocational High School

Bingol, Turkey

Mehmet KANAK

Assoc. Prof. Dr., Sivas Cumhuriyet University

Education Faculty

Sivas, Turkey
Original scientific paper

UDC: 37.013 .77

DOI: $10.5937 /$ IstrPed2102501C

\title{
AN INVESTIGATION OF THE RELATIONSHIP BETWEEN THE NARCISSISM LEVELS AND SELF-SABOTAGE LEVELS OF UNIVERSITY STUDENTS'
}

\begin{abstract}
The purpose of the present research is to determine the university students' levels and tendencies of narcissism, which is the subject of the research conducted in many different fields, to reveal its relationship with self-sabotage, which has been studied in recent years in Turkey, especially in the field of educational sciences, more specifically in the field of psychological counselling and guidance, and to discuss it according to various variables. The study group consists of 580 students who continue their education in different faculties and colleges in a university of a middle-sized province Central Campus in the 2018-2019 academic year. The researchers used the simple random sampling method in determining the study group. Measurement tools used in the research are the Narcissistic Personality Inventory, the Self-Sabotage Scale and the Demographic Information Form. To assess the relationship between the variables, independent samples t-test, one-way variance analysis (One Way ANOVA), Post Hoc tests, Levene homogeneity of variance test, regression analysis and Pearson correlation coefficient were used. The results of the study revealed that the narcissistic personality scores differed depending on the faculties in which the students were studying and the gender of the students. The results indicated no other differences in terms of other variables.
\end{abstract}

Key Words: Narcissism, self-sabotage/self-handicapping.

\section{Introduction}

Each person is different. According to Aslan and Saglam Ari (2018), one of the elements that make people different is personality. Personality begins to develop while individuals are still in the womb and it forms especially in the first years of life. Numerous variables affect the personality of individuals. These variables affect individuals at different times and different rates, thereby shaping their personality. From time to time, various problems may arise in personality development, and these problems cause the individual to deviate from normal and negatively affect personality development. One of the deviations that individuals may encounter in personality development is narcissism.

In today's society, narcissism has become a highly expressed concept; thus, it has become one of the favourite words of people. Twenge and Campbell (2015: 355) express this situation as

\footnotetext{
${ }^{1}$ This study was produced from Merve Çelik's master thesis with the same title.
} 
"narcissism is more easily spread than the fast-food chains. You have to construct neither buildings nor cook or recruit staff". The word narcissism, which is based on a mythological origin as a term, has been considered as a perversion in the psychiatric literature long ago, and it was first used by the English sexologist Havelock Ellis to describe a perverse behaviour. Then, Paul Nacke published an article summarizing Ellis's article in German with comments in 1899. Nacke first used the word narcissism as 'narcismus' in German. Therefore, Nacke is thought to be the person who coined the term narcissism (Ozen, 2016). According to Nacke (1899), Havelock Ellis considered narcissism as sexual perversion, linked it to autoeroticism, and stated that this was more common in women. However, the relevant literature has revealed that the understanding of narcissism has shifted in a different direction from this point of view, and it has been used in classifications related to personality disorders in the field of psychology. Narcissism is considered a multi-dimensional concept. Various researchers state that pathological narcissism, which impairs the functionality of the individual, has two different dimensions: grandiose and fragile (Eldogan, 2016).

Combating symptoms in individuals with a tendency to narcissism or a diagnosis of a narcissistic personality disorder requires intensive psychotherapy. Nevertheless, early detection of this condition in individuals with narcissistic tendencies allows making the required interventions earlier. This deviation in the personality of the individual can be transformed into a form by which the individual can live in harmony with society with the help of psychological counselling.

Similar to narcissism, the concept of self-sabotage has serious effects on the personality of individuals. Uzbe and Bacanli (2015: 34) state that "the individual uses different strategies to cope with the negative conditions and self-destructive behaviours that failure will create". One of these strategies is self-sabotage. The relevant literature uses the terms "self-sabotage" and "self-handicapping" interchangeably. Berglas and Jones (1978) define self-sabotage as the choice of an action or performance that provides the opportunity to find excuses for failure or allows one to adopt and internalize success. According to Akin, Abaci and Akin (2011), selfsabotage presents a contradictory structure, and this structure protects the self-esteem of the individual and manages the perceptions of the individual who monitors and evaluates himself/herself. On the other hand, it affects performance negatively.

Also, self-sabotage can manifest itself in individuals in different ways. According to Leary and Shepperd (1986), there are two types of self-handicapping. The first one involves putting real barriers to performance. In this case, being successful at work becomes more difficult and the imbalance increases. This can lead to situations such as drug and alcohol use. The other type is the verbal one. The performance has been hampered by factors beyond control. In the verbal self-handicapping strategy, the individual expresses barriers verbally. It is possible to talk about the positive and negative aspects of both self-handicapping strategies.

In Turkey, the studies addressing issues of self-sabotage are quite new. Akin (2012) adapted the Self-Sabotage Scale to Turkish. After the adaption of this scale to Turkish, the number of articles and theses on self-sabotage began to increase.

According to Twenge and Campbell (2015: 74), "narcissists love to win, however, they are not so good at winning in most environments." Here, the concept of self-sabotage, a strategy that the individual follows from time to time to protect his/her self and personality, emerges; thus, the following questions gain importance, do individuals with a high narcissistic tendency resort to self-sabotage, or may individuals with a high narcissistic tendency resort to self-sabotage more? 
The present study conducted in the light of these questions aimed to reveal the relationship between narcissism and self-sabotage, and the study examined the relationship between narcissism and self-sabotage according to several demographic variables. The researchers have observed that there are not many studies on the relationship between narcissism and selfsabotage. The researchers believe that this research will contribute to the literature which is lacking in examining the relationship between narcissism and self-sabotage. Furthermore, this study is considered valuable in terms of associating and examining narcissism and selfsabotage.

\section{Method}

\section{Research Method}

This study, in which quantitative methods are employed since it examines the relationship between the narcissism levels of university students and their self-sabotage level, uses a relational screening model. Karasar (2014) defines the relational screening model as a research model that aims to determine the variation of two or more variables together or the degree of this variation.

\section{Population and Sampling}

The researchers used a study group in this research. The study group consisted of students who continued their education in different faculties and colleges at a state university in a mediumsized province in the Central Anatolia Region in the 2018-2019 academic year. The study group consisted of 580 people. 339 of them were female and 241 were male.

\section{Data Collection Tools}

The researchers used two measurement tools as data collection tools. The first of these measurement tools is the Narcissistic Personality Inventory, the 16-item version of which was standardized to Turkish by Atay (2009) and re-adapted to Turkish by Gungor and Selcuk (2015). The other tool is the Self-Sabotage Scale. Akin (2012) carried out a validity and reliability study. In addition to these measurement tools, the researchers used the Demographic Information Form to access information to be used as variables, including the number of siblings, birth order in their families, socio-economic level of their families, place where they spend most of their lives, their gender, their age, their faculties and grade levels, about the participants.

\section{Data Collection and Analysis}

The measurement tools were given to 580 students who continued their education in different faculties and colleges in a state university in a middle-sized province in the Central Anatolia Region at times determined in accordance with the study schedule. The data obtained from 580 students were analyzed by importing them into the IBM SPSS 23 software package. Since the skewness and kurtosis coefficients of the data were within normal limits, no action was taken regarding the extreme values, thus, the data were analyzed as they were. The missing data analysis was performed for the missing data in the study, and the results indicated that the data did not show a systematic distribution. Therefore, the average values were assigned instead of missing data. Kolmogorov-Smirnov test was performed to test the normality of the data. Independent groups t-test was used for variables consisting of two categories, while one-way analysis of variance (ANOVA) was used for variables consisting of three or more categories. In case of a difference in the results of the ANOVA test, multiple comparison (Post Hoc) tests were 
run to locate the difference between the groups. In determining the multiple comparison tests to be used, Levene's test for homogeneity of variances was run. According to the results of this test, Tukey multiple comparison test was used when group variances were homogeneous, and Tamhane T2 multiple comparison test was used when the group variances were not homogeneous.

Finally, the relationship between students' narcissistic personality scores and self-sabotage levels was examined by calculating the Pearson correlation coefficient.

\section{Findings and Comments}

This section presents the findings obtained based on the collected data and the interpretations of the findings.

Table 1: Results of the ANOVA of the Narcissistic Personality Scores of the students by Their Faculties

\begin{tabular}{lllllll}
\hline Variable & Variance Source & $\begin{array}{l}\text { Sum of } \\
\text { Squares }\end{array}$ & $\begin{array}{l}\text { Degree of } \\
\text { Freedom }\end{array}$ & Mean Squares & F & P \\
\hline \multirow{2}{*}{ Narcissistic } & Inter-Group & 77.434 & 6 & 12.906 & 3.484 & $\mathbf{0 . 0 0 2}$ \\
Personality & Intra-Group & 2122.482 & 573 & 3.704 & & \\
& Total & 2199.917 & 579 & & \\
\hline
\end{tabular}

The results of the ANOVA determined a significant difference between the narcissistic personality levels of university students and faculty they studied in $(F=3.484, p<.05)$. Tukey multiple comparison test was carried out to locate the difference. Table 2 presents the findings.

Table 2: Results of Tukey Multiple Comparison Test

\begin{tabular}{|c|c|c|c|c|}
\hline Variable & Group 1 & Group 2 & $\begin{array}{l}\text { Difference in } \\
\text { Means }\end{array}$ & $\mathbf{P}$ \\
\hline \multirow{14}{*}{$\begin{array}{l}\text { Narcissistic } \\
\text { Personality }\end{array}$} & \multirow{9}{*}{$\begin{array}{l}\text { Vocational School } \\
\text { of Health } \\
\text { Services }\end{array}$} & Education & -.16661 & .999 \\
\hline & & $\begin{array}{l}\text { Faculty of Economics and } \\
\text { Administrative Sciences }\end{array}$ & -1.06236 & .015 \\
\hline & & Literature & -.77360 & .187 \\
\hline & & Pharmacy & -.70225 & .446 \\
\hline & & Theology & -1.08412 & .007 \\
\hline & & ... Vocational School of ... & -.73098 & .262 \\
\hline & & Department of PES & -.76726 & .246 \\
\hline & & Education & .89575 & .094 \\
\hline & & Vocational School of Health Services & 1.06236 & .015 \\
\hline & \multirow{5}{*}{$\begin{array}{c}\text { Faculty of } \\
\text { Economics and } \\
\text { Administrative } \\
\text { Sciences }\end{array}$} & Literature & .28876 & .984 \\
\hline & & Pharmacy & .36010 & .970 \\
\hline & & Theology & -.02176 & 1.000 \\
\hline & & ... Vocational School of ... & .33138 & .967 \\
\hline & & Department of PES & .29509 & .986 \\
\hline
\end{tabular}

The results of the Tukey multiple comparison test indicated that the narcissistic personality levels of students studying in the Faculty of Economics and Administrative Sciences, and the Faculty of Theology were significantly higher than those studying in the Vocational School of Health Services. The results did not indicate any other significant difference. 
Table 3: Results of the T-Test between Self-Sabotage Scores and the Gender Variable

\begin{tabular}{lllllll} 
Variable & Gender & $\mathbf{n}$ & $\overline{\mathbf{x}}$ & $\mathbf{S d}$ & $\mathbf{t}$ & $\mathbf{p}$ \\
\hline \multirow{2}{*}{ Self-Sabotage } & Male & 241 & 94.22 & 12.154 & -3.427 & $\mathbf{0 . 0 0 1}$ \\
& Female & 339 & 97.53 & 10.447 & & \\
\hline
\end{tabular}

The findings of the T-Test determined that there was a significant difference between the selfsabotage levels of university students and their gender $(t=-3.427, p<.05)$. Considering the average self-sabotage scores of gender groups, female students' self-sabotage level was found to be significantly higher than that of male students.

Table 4: Results of the ANOVA between the Self-Sabotage Scores of the Students and Their Faculties

\begin{tabular}{ccccccc}
\multirow{2}{*}{ Variable } & Variance Source & $\begin{array}{c}\text { Sum of } \\
\text { Squares }\end{array}$ & $\begin{array}{c}\text { Degree of } \\
\text { Freedom }\end{array}$ & Mean Squares & F & P \\
\hline \multirow{3}{*}{ Self-Sabotage } & Inter-Group & 4140.068 & 7 & 591.438 & 4.850 & $\mathbf{0 . 0 0 0}$ \\
& Intra-Group & 69747.096 & 572 & 121.935 & & \\
& Total & 73887.164 & 579 & & & \\
\hline
\end{tabular}

The results of the ANOVA indicated a significant difference between the self-sabotage levels of university students and their faculties $(F=4.854, p<.05)$. Tamhane $T 2$ test, which is one of the multiple comparison tests used when the group variances are not homogeneous, was run to find out the difference, and Table 5 presents the findings.

Table 5: Results of Tamhane T2 Multiple Comparison Test According to the Faculties

\begin{tabular}{|c|c|c|c|c|}
\hline Variable & Group 1 & Group 2 & $\begin{array}{l}\text { Difference in } \\
\text { Means }\end{array}$ & p \\
\hline Self- & Literature & Education & 1.10566 & 1.000 \\
\hline \multirow[t]{22}{*}{ Sabotage } & & $\begin{array}{l}\text { Vocational School of Health } \\
\text { Services }\end{array}$ & 1.17668 & 1.000 \\
\hline & & $\begin{array}{l}\text { Faculty of Economics and } \\
\text { Administrative Sciences }\end{array}$ & .16575 & 1.000 \\
\hline & & Pharmacy & 6.28786 & .023 \\
\hline & & Theology & 2.23562 & .991 \\
\hline & & ... Vocational School of ... & 6.01813 & .012 \\
\hline & & Department of PES & 7.06279 & .024 \\
\hline & Pharmacy & Education & -5.18220 & .151 \\
\hline & & $\begin{array}{l}\text { Vocational School of Health } \\
\text { Services }\end{array}$ & -5.11117 & .169 \\
\hline & & $\begin{array}{l}\text { Faculty of Economics and } \\
\text { Administrative Sciences }\end{array}$ & -6.12210 & .117 \\
\hline & & Literature & -6.28786 & .023 \\
\hline & & Theology & -4.05223 & .584 \\
\hline & & ... Vocational School of ... & -.26973 & 1.000 \\
\hline & & Department of PES & .77493 & 1.000 \\
\hline & ... Vocational & Education & -4.91247 & .110 \\
\hline & School of... & $\begin{array}{l}\text { Vocational School of Health } \\
\text { Services }\end{array}$ & -4.84144 & .125 \\
\hline & & $\begin{array}{l}\text { Faculty of Economics and } \\
\text { Administrative Sciences }\end{array}$ & -5.85237 & .096 \\
\hline & & Literature & -6.01813 & .012 \\
\hline & & Pharmacy & .26973 & 1.000 \\
\hline & & Theology & -3.78250 & .541 \\
\hline & & Department of PES & 1.04466 & 1.000 \\
\hline & Department of PES & Education & -5.95713 & .130 \\
\hline & & $\begin{array}{l}\text { Vocational School of Health } \\
\text { Services }\end{array}$ & -5.88610 & .144 \\
\hline
\end{tabular}




\begin{tabular}{lll}
\hline Faculty of Economics and & -6.89703 & .094 \\
Administrative Sciences & & \\
Literature & -7.06279 & .024 \\
Pharmacy & -.77493 & 1.000 \\
Theology & -4.82716 & .472 \\
$\ldots$ Vocational School of ... & -1.04466 & 1.000 \\
\hline
\end{tabular}

The Tamhane multiple comparisons showed that there were significant differences between the students studying in the faculty of literature, and those studying in the faculty of pharmacy, the Vocational School of ... and the Department of Physical Education and Sports (PES). Considering the group averages, the study can conclude that the self-sabotage levels of the students studying in the faculty of pharmacy, the Vocational School of ...., and the Department of PES were significantly higher than the students studying in the faculty of literature. Besides these differences, the test indicated no other significant difference.

Table 6: Pearson Correlation Coefficient between Narcissistic Personality Level and Self-Sabotage Level

$$
\text { Narcissistic Personality Self-Sabotage }
$$

\begin{tabular}{llll}
\hline & $\mathrm{r}$ & 1.000 & -0.080 \\
Narcissistic & & & \\
Personality & $\mathrm{p}$ & 0.000 & 0.053 \\
& $\mathrm{n}$ & 580 & 580 \\
\cline { 2 - 4 } & $\mathrm{r}$ & -0.080 & 1.000 \\
& & & \\
Self-Sabotage & $\mathrm{p}$ & 0.053 & 0.000 \\
& $\mathrm{n}$ & 580 & 580 \\
\hline
\end{tabular}

The results of correlation analysis indicated no significant correlation between narcissistic personality levels and self-sabotage levels of university students $(r=-0.080, p>.05)$. In other words, although a very weak and negative correlation appeared between the two variables, this correlation was not statistically significant. At this stage, although there was no significant correlation between the two variables, a simple linear regression analysis was run assuming that students' narcissistic personality scores may be predictors of their self-sabotage levels. The findings obtained from the results of the regression analysis are presented in Table 7.

Table 7: The Results of Regression Analysis on Whether the Self-Sabotage Levels of the Students are Affected by Their Narcissistic Personality Levels

\begin{tabular}{clllllll}
$\begin{array}{l}\text { Dependent } \\
\text { Variable }\end{array}$ & $\begin{array}{l}\text { Independent } \\
\text { Variable }\end{array}$ & $\boldsymbol{\beta}$ & $\mathbf{t}$ & $\mathbf{P}$ & $\mathbf{F}$ & $\begin{array}{c}\text { Model } \\
(\mathbf{p})\end{array}$ & $\mathbf{R}^{2}$ \\
\hline $\begin{array}{c}\text { Self- } \\
\text { Sabotage }\end{array}$ & $\begin{array}{l}\text { Constant } \\
\text { Narcissistic }\end{array}$ & 107.422 & 18.397 & 0.000 & 3.749 & 0.053 & 0.006 \\
& Personality & -0.465 & -1.936 & 0.053 & & & \\
\hline
\end{tabular}

The findings of regression analysis indicated that the regression model established to test whether the self-sabotage levels of university students were affected by their narcissistic personality levels was not found to be statistically significant $(F=3.749, p>.05)$. According to this model, although the narcissistic personality levels of university students were found to have a negative effect on their self-sabotage levels, this regression relationship did not yield statistically significant results $(B=-0.465 ; t=-1.936, p>.05)$. 


\section{Discussion and Conclusion}

The current study investigated whether there was a significant relationship between narcissistic personality levels of university students and their gender, and the results indicated no significant difference. This is in good agreement with Erdem (2013). Furthermore, the results have a number of similarities with Demiralp's (2017) findings; however, he found that males scored higher than females in the sufficiency sub-dimension.

In terms of self-sabotage levels of university students, female students' self-sabotage levels were found to be significantly higher than male students' self-sabotage levels. Kalyon, Dadandi and Yazici (2016) found similar results. In addition, Sheppard and Arkin (1989) and Strube and Roemmele (1985) concluded that females' self-sabotage levels were higher than those of males. The studies conducted by Buyukgoze \& Gun (2015), Anli, Akin, Sar, and Eker (2015), and Zuckerman and Tsai (2005) reported that there were no significant relationships between the self-sabotage levels and the gender variable. Berglas and Jones (1978), Midgley, Arunkumar and Urdan (1996), and Urdan \& Midgley (1998) found that males' self-sabotage levels were higher than those of females.

Narcissistic personality levels of students studying at the Faculty of Economics and Administrative Sciences and Faculty of Theology were significantly higher than those studying at the Vocational School of Health Services. Erdem (2013) also found similar results regarding the students of the Faculty of Economics and Administrative Sciences. It is an interesting result that the narcissistic personality tendency was found to be high in students studying at the Faculty of Theology. This situation may be due to the fact that students studying in the Faculty of Theology consider themselves better and superior to other people in various subjects, especially in religious issues. On the other hand, for the students studying at the Department of Physical Education and Sports, this situation might be due to the fact that these students have lower academic performance in general, but they have a special interest in sports. Moreover, excessive self-esteem in these individuals may prevent them from facing failure, and this leads to higher self-sabotage. Lower self-sabotage among students studying at the Faculty of Literature may be due to the fact that these individuals are more realistic to the events and have fewer problems in facing their failures. The self-sabotage levels of the students studying in the Faculty of Pharmacy, Vocational School of ..., and Department of Physical Education and Sports were found to be significantly higher than those of the students studying in the Faculty of Literature. Demiralp (2017) did not find a significant relationship between the sub-dimensions of the narcissistic personality and the faculty variable either.

The results also indicated that the narcissistic personality levels and self-sabotage did not show a significant difference according to the variables of age, grade level, and the number of siblings. Uzbe (2013) also found similar results regarding the grade level. Fleming (2007) found that the self-sabotage level increased as the grade level increased. In terms of the number of siblings, considering that the narcissistic tendency decreases as the number of siblings increases, it is very interesting that the narcissistic personality tendency did not differ according to the number of siblings variable. Demiralp (2017) found a difference between authority, which was one of the sub-dimensions of the narcissistic personality, and the number of siblings.

The study indicated that the narcissistic personality levels and self-sabotage levels did not differ significantly according to the students' order of birth in their families. At the beginning of the research, the researchers had believed that the narcissistic personality level might be higher in the first child of the family due to the fact that parents are more interested in their first child and more concentrated on the first child. Furthermore, the researchers had thought that self- 
sabotage levels may be higher in the first child as they may develop dependent personalities due to wrong parenting practices in the first children. In addition, the researchers had believed that the narcissistic personality level may be higher in the last children of the families since they have more freedom and make their parents do whatever they want more easily. Nevertheless, the results of the research contradict these, and the study concluded that the narcissistic personality tendency and self-sabotage did not differ according to the students' birth order in their families.

The results indicated that the narcissistic personality and self-sabotage levels of university students did not differ according to the variables of the place where the students spent most of their lives and the monthly income level of their families. The fact that the narcissistic personality levels did not differ according to the monthly income levels of the families variable can mean that the narcissistic personality tendency is not affected by such external sources, or that the increase in purchasing power in people in general may cause the narcissistic personality tendency.

Although a very weak and negative correlation was found between the narcissistic personality level and the self-sabotage level of university students, this correlation was not statistically significant. This situation may be due to the possibility that the participants did not give honest responses to some items in the self-sabotage scale due to the social desirability phenomenon. Another possibility might be that the narcissistic personality tendency and the self-sabotage tendency concepts do not correspond to each other. Similar to the results of the present study, Kalyon, Dadandi and Yazici (2016), and Rhodewalt, Tragakis and Finnerty (2005) did not find a significant relationship between narcissistic personality level and self-sabotage level.

The results indicated that the self-sabotage levels of the university students participating in the study were above average. In line with these results, the following recommendations can be made. First, the self-sabotage levels of students can be determined in schools, and then, practices can be implemented to decrease the self-sabotage levels of the individuals whose selfsabotage levels are above the average. To examine whether the narcissistic personality levels and self-sabotage levels vary according to the age variable, new cross-sectional and longitudinal studies can be conducted. The fact that the narcissistic personality levels and self-sabotage levels differ according to some variables and do not differ according to other variables can be studied by conducting experimental research, and the reasons for these situations can be examined. The research can be replicated by different researchers using students from different grade levels, larger sample groups, and different scales.

\section{NOTES:}

\section{Ethical Approval}

All procedures performed in studies involving human participants were in accordance with the ethical standards by the 1964 Helsinki declaration and its later amendments or comparable ethical standards.

\section{Informed Consent}

Informed consent was obtained from all individual participants included in the study.

\section{Conflict of Interest}

On behalf of all authors, the corresponding author states that there is no conflict of interest. 


\section{References:}

Akin, A., Abaci, R., \& Akin, U. (2011). Kendini sabotaj: Kavramsal bir analiz. International Online Journal of Educational Sciences; 3(3): 1155-1168.

Akin, A. (2012). Kendini sabotaj olcegi: Gecerlik ve guvenirlik calismasi. Egitim ve Bilim; 37(164): 177- 187.

Anli, G., Akin, A., Sar, A. H. \& Eker, H. (2015). Kendini sabotaj ile psikolojik iyi olma arasındaki iliskinin cesitli degiskenler acisindan incelenmesi. Elektronik Sosyal Bilimler Dergisi, 14(54): 160-172.

Aslan, Z. \& Saglam Ari, G. (2018). Kisilik ve duygusal emek arasindaki iliskilerin belirlenmesi uzerine bir arastirma: Banka calısanlari ornegi. Pamukkale Universitesi Sosyal Bilimler Enstitusu Dergisi, 30: 157-171. Doi:10.5505/pausbed.2018.86548.

Atay, S. (2009). Narsistik kisilik envanteri'nin Turkce'ye standardizasyonu. Gazi Universitesi Iktisadi ve Idari Bilimler Fakultesi Dergisi, 11(1): 181-196.

Berglas, S. \& Jones, E. E. (1978). Drug choice as self-handicapping strategy in response to noncontingent success. Journal of Personality and Social Psychology, 95(4): 405-417.

Buyukgoze, H. \& Gun, F. (2015). Arastirma gorevlilerinin kendini sabotaj egilimlerinin incelenmesi. Hitit Universitesi Sosyal Bilimler Enstitusu Dergisi; 8(2): 689-704. doi: http://dx.doi.org/10.17218/husbed.11352.

Erdem, A. (2013). Universite ogrencilerinin flort siddetine yonelik tutumlari, toplumsal cinsiyetcilik ve narsisistik kisilik ozellikleri arasindaki iliski. (Yayinlanmamis yuksek lisans tezi). Gazioamanpasa Universitesi/ Egitim Bilimleri Ana Bilim Dali, Rehberlik ve Psikolojik Dansma Bilim Dali, Tokat.

Demiralp, C. (2017). Universite Ogrencilerinin Empatik Egilim Ile Narsistik Kisilik Ozellikleri ve Elestirel Dusunme Arasindaki Iliskinin Incelenmesi. (Yayinlanmamis yuksek lisans tezi). Ataturk Universitesi/ Egitim Bilimleri Enstitusu, Egitim Bilimleri Ana Bilim Dali, Rehberlik ve Psikolojik Danismanlık Bilim Dali, Erzurum.

Eldogan, D. (2016). Hangi narsizm? Buyuklenmeci ve kirilgan narsizmin karsilastirilmasina iliskin bir gozden gecirme. Turk Psikoloji Yazilari, 9(37): 1-10.

Fleming, S. D. (2007). Perception of ability, trait affectivity, and selfhandicapping behavior in adolescents (Doctoral dissertation). Retrived from ProQuest Dissertations and Thesis Database. (UMI No: 3244139).

Gungor, N. D. \& Selcuk, F. U. (2015). Narsisistik kisilik envanteri (NKE-16) Turkce uyarlamasi. Atilim Universitesi Sosyal Bilimler Arastırma ve Egitim Laboratuvari (SAEL), Yayinlanmamis Tartisma Metni, sael.atilim.edu.tr.

Kalyon, A., Dadandi, I. \& Yazici, H. (2016). Kendini sabote etme egilimi ile narsistik kisilik ozellikleri, anksiyete duyarliligi, sosyal destek ve akademik basari arasindaki iliski. Dusunen Adam The Journal of Psychiatry and Neurological Sciences; 29(3): 237-246. doi: 105350/DAJPN2016290305.

Karasar, N. (2014). Bilimsel arasatirma yontemi “kavramlar ilkeler teknikler"(27. Basim). Nobel.

Leary, M. R. \& Sheppard, J. A. (1986). Behavioral self-handicaps versus self-reported selfhandicaps: A Conceptual note. Journal of Personality and Social Psychology, 51: 12651268.

Midgley, C., Arunkumar, R. \& Urdan, T. C. (1996). If I don't do well tomorrow, there's a reason: Predictors of adolescents' use of academic self-handicapping strategies. Journal of Educational Psychology, 88(3): 423-434.

Nacke, P. (1899). Die sexuellen perversitaten in der irrenanstalt. Psychiatrische en Neurologische Bladen, 3: 20-30.

Ozen, Y. (2016). Narsistik ben kendilik psikolojisi baglaminda. Gece Kitapligi. 
Rhodewalt, F., Tragakis, M. W. \& Finnerty, J. (2005). Narcissism and self-handicapping: Linking self-aggrandizement to behavior. Journal of Research in Personality, 40: 573-597. Doi: 10.1016/j.jrp.2005.05.001

Shepperd, J. A. \& Arkin, R. M. (1989). Determinants of self-handicapping: Task importance and the effects of pre-existing handicaps on self-generated handicaps. Personality and Social Psychology Bulletin, 15: 101-112.

Strube, M. J. \& Roemmele, L. A. (1985). Self-enhancement, self-assessment and self-evaluative task choice. Journal of Personality and Social Psychology, 49:981-993.

Twenge, J. M. \& Campbell, W. K. (2015). Asrin vebasi: Narsisizm illeti. (Cev. Ozlem Korkmaz) 3. Basim. Istanbul: Kaknus. Orijinal Basım Tarihi: 2009.

Urdan, T. \& Midgley, C. (2001). Academic self-handicapping: What we know, what more there is to learn? Educational Psychology Review, 13(2): 115-138.

Uzbe, N. (2013). Basari Hedef Yonelimi, Benlik Saygisi ve Akademik Basarinin Kendini Engellemeyi Yordamadaki Rolu. (Yuksek lisans tezi). Gazi Universitesi/Egitim Bilimleri Enstitusu, Ankara.

Uzbe, N. \& Bacanli, H. (2015). Basari hedef yonelimi, benlik saygisi ve akademik basarinin kendini engellemeyi yordamadaki rolu. Turk Egitim Bilimleri Dergisi; 13(1): 33-50.

Zuckerman, M. \& Tsai, F. F. (2005). Cost of self-handicapping. Journal of Personality, 73(2): 411442. Doi: 10.1111/j.1467-6494.2005.00314x.

\section{Biographical notes:}

Lecturer Merve Celik - The author, who completed her undergraduate education in the Department of Psychological Counselling and Guiadance at Sivas Cumhuriyet University in 2016, completed her master's degree in 2019 at the educational sciences institute of the same university.Started her academic studies as a lecturer at Bingöl University in 2020.

Author's study topics; School psychological counselling, child protect, psychodrama

Assoc. Prof. Mehmet KANAK - Completed his bachelor's degree in preschool education at Cumhuriyet University in 2007, and master degree in preschool education at Inonu University in 2011 and PhD degree in child development and education at Gazi University in 2015. After two years of teaching experience at schools affiliated to the ministry of education, he began his academic studies as a lecturer at Hitit University in 2009. He started to work as a lecturer at Cumhuriyet University in 2013 and worked as an Assistant Professor between 2015-2019. Since 2019 he has been working as an Assoc. Prof. at the same university. He has studies in child abuse and neglect, preschool education, child development and teacher training. 